\title{
MRI ASSESSMENT OF MUSCULAR LESIONS IN LOWER LIMB
}

\author{
Hanan M. Arafa ${ }^{1}$, Gamal Niazi ${ }^{1}$, Menetallah Hatem ${ }^{1}$, Sherif Elhenawy ${ }^{2}$, \\ Dina O.Mohammed ${ }^{2}$ and Yara M. Ahmed ${ }^{3}$
}

1- Department of Radiodiagnosis, Faculty of Medicine, Ain Shams University

${ }^{2-}$ Department of

Radiodiagnosis, Research institute of ophthalmology

${ }^{3-}$ General organization for teaching hospitals and institute

Corresponding :

Dina Osama M Helmy Mobile01119991515,

E mail:

dinaosama1983@gmail.com

Received: 31/7/2019

Accepted: 29/8/2019

\begin{abstract}
Background: Muscle disease is a disorder caused by derangement of the structure or function of muscle fiber, blood supply and/or connective tissue element of the muscle the combination of clinical examination and MRI could improve the accuracy of phenotypic characterization of patients with muscular lesions, This may also be very helpful in the assessment of the degree of muscle compromise not only in the early phases of the disease but also during the follow-up and can be used especially in therapeutic trials.
\end{abstract}

Aim of the work: To assess the role of MRI in detection and evaluation of muscle diseases and its prognostic value for the follow up.

Patients and Methods: This study was conducted at the radiology department Ain Shams university, it included thirty patients, they all had clinical diagnosis have of muscular diseases of the lower limb, fulfilled inclusion criteria.

Results: The sensitivity of MRI in detection of malignant lesions compared to histo-pathology and clinical diagnosis as gold standered was $83.3 \%$, specificity was $91.7 \%$ and accuracy was $90 \%, 76.7 \%$ of the studied cases had a benign which was lesion most frequently a hemangioma (10\%), also $23.3 \%$ of the patients had a malignant lesion which was most frequently metastasis from other tumors (13.3\%).

Conclusion: MRI is the modality of choice in evaluating lower limb muscular lesions due to its high soft tissue contrast resolution, and multi-planar capabilities. MRI may allow clinicians to more accurately estimate the time required before patient can return to normal life as well as the risk of recurrent injury. lesions.

Key word: Magnetic resonance image, lower limb muscular

\section{INTRODUCTION:}

Muscle disease is a disorder caused by derangement of the structure or function of muscle fiber, blood supply and/or connective tissue element of the muscle ${ }^{(1)}$, the combination of clinical examination and MRI could improve the accuracy of phenotypic characterization of patients with muscular dystrophy, and this in turn could allow a more focused molecular analysis through muscle biopsy or genetic investigation. This may also be very helpful in the assessment only in the early phases of the disease but also during the follow-up and can be used especially in therapeutic trials ${ }^{(2)}$, recently introduced advanced and quantitative MRI methods are quite promising including T2 relaxation time measurements and magnetic resonance spectroscopy. However, it is challenging in terms of quantification and of the degree of muscle compromise not 
further specification of the disease process and disease monitoring ${ }^{(3)}$.

\section{AIM OF THE WORK:}

To assess the role of MRI in detection and evaluation of muscle diseases and its prognostic value for the follow up.

\section{PATIENTS AND METHODS:}

1) Study population: This study was conducted at the radiology department Ain Shams university during the period from October 2017 till January 2019, it included thirty patients, their ages ranged from 3 to 75 years ,they all had clinical diagnosis of muscular diseases of the lower limb with Ainclusion criteria that all patients in different age group and both sexes who presented with lower limb pain and clinical diagnosis of muscular lesions and B-Exclusion criteria: for any contraindication for MRI .

2) Methods: The study was performed on a 1.5 Tesla Philips achieva using a limb coil, sedation was needed in noncontrollable group (children), the patient was positioned supine on the MRI table with no special preparation needed and the study duration was about 30 minutes, the sequences used were as follows :

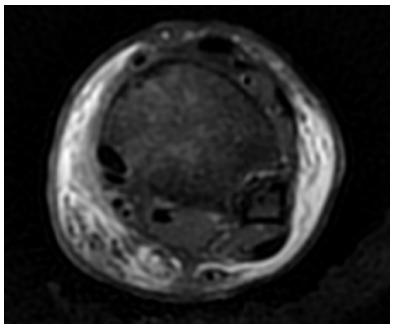

(A)

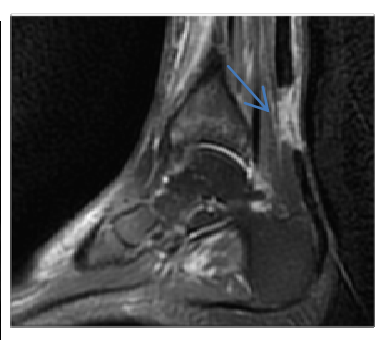

(B)

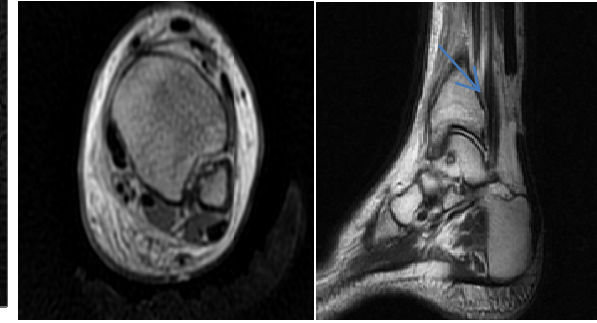

(C)
- Axial T1-Weighted image $(\mathrm{TR} / \mathrm{TE}=$ 400-700/14-30; FOV, 20-35).

- Sagittal T1- Weighted image(TR/TE = 2800-4500/80-120; FOV, 20-35).

- Axial short-tau inversion recovery STIR/T2-Weighted image .

- Sagittal short-tau inversion recovery STIR/T2-Weighted image.

- Coronal short-tau inversion recovery STIR/T2-Weighted image.

- Sagittal proton density .

\section{Cases:}

Case 1: A 23 year old male presented with pain in calf region after trauma during playing football, with MR Findings: loss of normal continuity and signal intensity of the Achilles tendon, displays iso-signal intensity at T1WI and high signal intensity at PDSTIR (A\&B) and T2WI (C\&D)of about $=3$ $\mathrm{cm}$ with distance from calcaneal attachment to the distal portion of the tear $=5.5 \mathrm{~cm}$ (Fig 1).there is also diffuse circumferential soft tissue edema displayed high signal intensity at PD-STIR and diagnosed as complete full thickness tear of the Achilles tendon (gap about $3 \mathrm{~cm}$ )

Fig 1

Case 2: A 35 year old male presented with history of trauma by instructs to the left leg, with MR Findings: abnormal muscular shape at the medial, lateral and posterior compartments of the upper $2 / 3$ of the leg with multiple flocculent masses of different sizes with partial skin involvement and inter- osseous extension, display mixed low and high signal intensities at both T1WI\&T2WI (A,B)with faint enhancement at post contrast study (C) (Fig 2) and diagnosed as Myositisossifficans. 


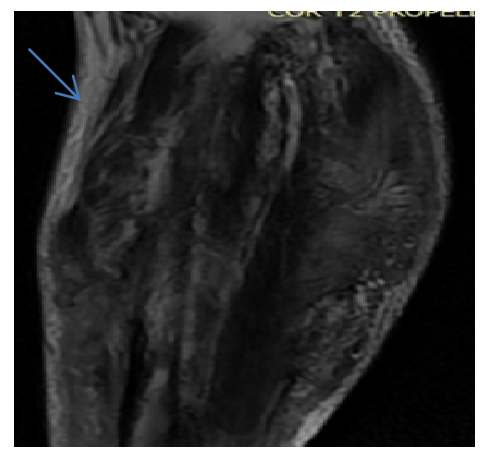

(A)

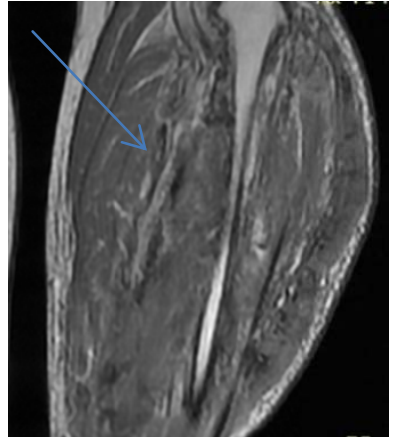

(B)

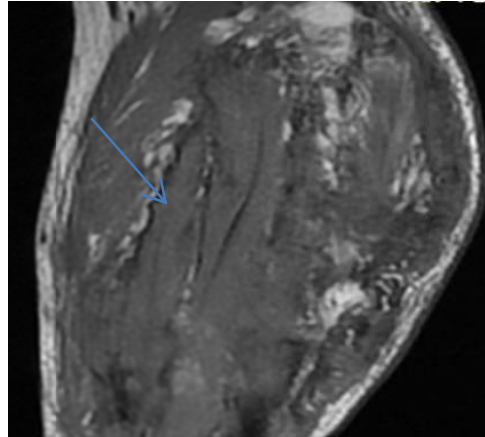

(C)

Fig 2

Case 3: A 59 year old male presented with history of surgically removed mass from right thigh and pathologically proven giant cell tumor with MR Findings: A welldefined globular shaped multilocular intramuscular cystic lesion measures about $45 \times 36 \times 35 \mathrm{~mm}$, at the right thigh muscles( lateral vastus muscle), displayes mixed hypo

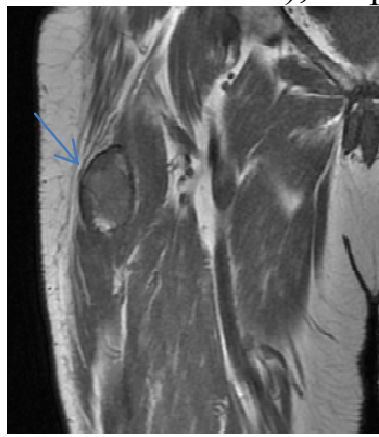

( A)

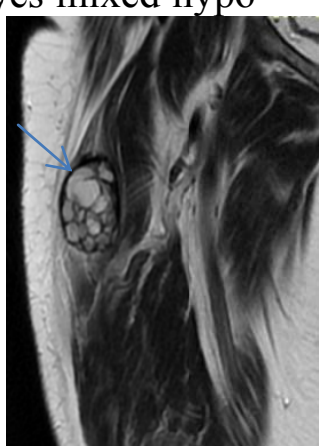

(B)

to iso intense signal at T1WI (A), mixed intermediate high signal at T2WI (B)and bright signal at PD-STIR (C\&D)with hemorrhagic components (Fig 3) and diagnosed as right upper lateral thigh intramuscular malignant lesion (recurrent giant cell tumor).

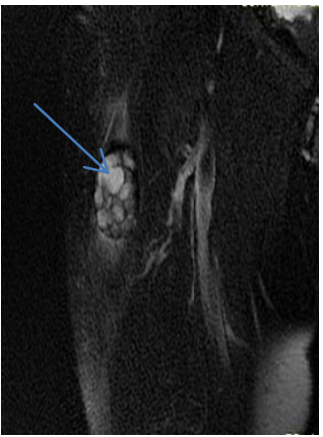

(C)

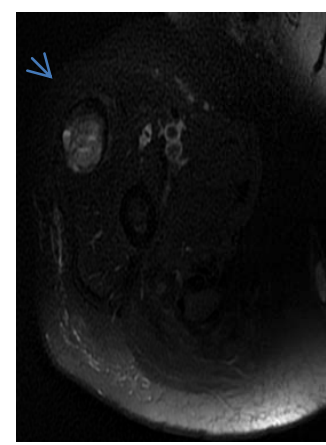

(D)

Fig 3

Case 4:A18 year old male presented with history of blow trauma during playing hocky with MR Findings: well defined oblong shaped intra-muscular mixed signal intensity lesion measuring about $53 \times 43 \times 35$ $\mathrm{mm}$ at the lateral aspect of the right leg

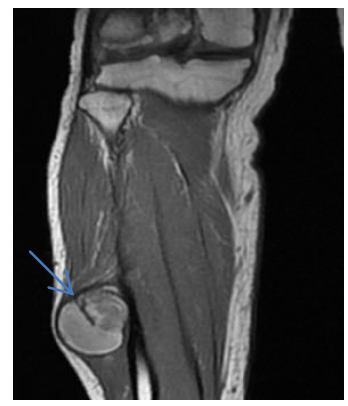

(A)

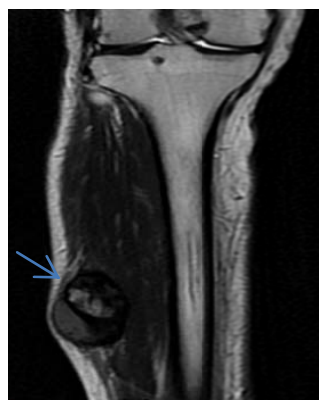

(B)

related the lower third of the fibula, displayed high signal intensity at T1WI (A)\& mixed low and high signal intensity at T2WI (B\&D)and bright at PD-STIR (C)(Fig 4) and diagnosed as Intra-muscular hematoma.

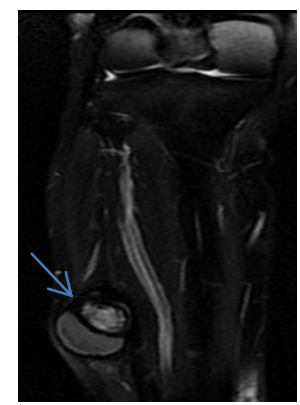

(C)

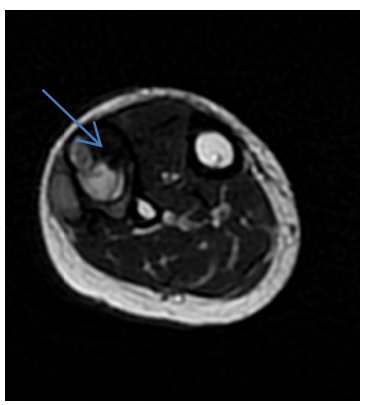

(D)

Fig 4 


\section{Hanan M. Arafa, et al.,}

Case 5: A 18 year old female presented with history of pain and swelling in the sole of left foot with MR Findings:Lobulated soft tissue lesion infiltrating the planter aspect of the left foot measures about $70 \times 35$ $\mathrm{mm}$ involving the underlying muscular
(A)

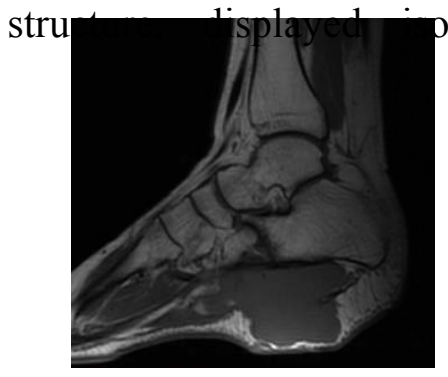

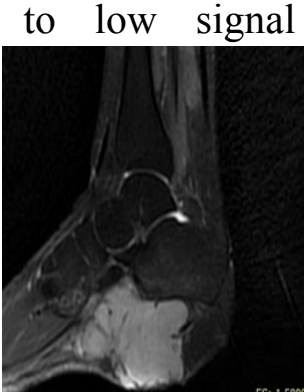

(B)
Fig 5 intensity at T1WI (A) and relative intermediate signal intensity at $\mathrm{T} 2 \mathrm{WI}$ and high signal intensity at PD-STIR (B\&C) with intense in-homogenous post contrast enhancement (D) (Fig 5) and diagnosis as fibrosarcoma.

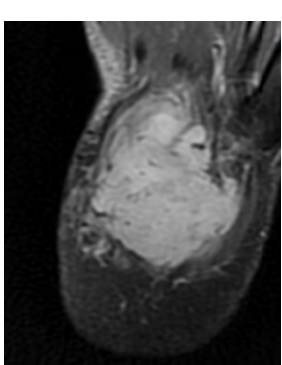

(C)

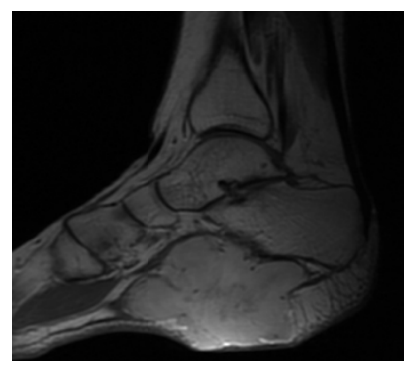

(D)
Table (2): Clinical data of the studied cases:

\section{Results:}

Table (1): Demographic data of the studied cases:

\begin{tabular}{|l|c|c|}
\hline Variable & \multicolumn{2}{|l|}{$(n=30)$} \\
\hline Age : (year) & \multicolumn{2}{|l|}{} \\
Mean \pm SD & \multicolumn{2}{|l|}{$36.37 \pm 21.53$} \\
Median & 36.5 \\
Range & $3-75$ \\
\hline Variable & No & $\%$ \\
\hline Sex: & & \\
Female & 12 & 40 \\
Male & 18 & 60 \\
\hline Occupation: & & \\
Not working & 4 & 13.3 \\
House wife & 5 & 16.7 \\
Student & 7 & 23.3 \\
Farmer & 5 & 16.7 \\
Skilled & 1 & 3.3 \\
Specialist & 8 & 26.7 \\
\hline Residence: & & \\
Rural & 13 & 43.3 \\
Urban & 17 & 56.7 \\
\hline
\end{tabular}

\begin{tabular}{|l|c|l|}
\hline \multirow{2}{*}{ Variable } & \multicolumn{2}{|l|}{$(\mathrm{n}=30)$} \\
\cline { 2 - 3 } & No & $\%$ \\
\hline Type: & 20 & 66.7 \\
Non traumatic & 10 & 33.3 \\
Traumatic & 5 & 16.7 \\
During sport & 4 & 13.3 \\
Instrument or object & 1 & 3.3 \\
Fall from stairs & & \\
Symptoms: & 11 & 36.7 \\
Pain & 5 & 16.7 \\
Swelling & 2 & 6.7 \\
Skin discoloration & 1 & 3.3 \\
Difficult in movement & 1 & 3.3 \\
Muscle weakness & 1 & 3.3 \\
Osteoarthritic change & 1 & 3.3 \\
Size fluctuation & 1 & 3.3 \\
Night sweat & 1 & 3.3 \\
Malaise & & \\
Systematic comorbidity: & 28 & 93.3 \\
No & 2 & 6.7 \\
Yes & 1 & 3.3 \\
Cancer breast & 1 & 3.3 \\
Hemolytic disorder & \multicolumn{2}{|l}{} \\
\hline
\end{tabular}


Table (3): Investigation results among the studied cases:

\begin{tabular}{|l|c|c|}
\hline Variable & \multicolumn{2}{|c|}{$(\mathrm{n}=30)$} \\
\cline { 2 - 3 } & No & $\%$ \\
\hline Pathology: & 10 & 33.3 \\
Benign & 4 & 13.3 \\
Lipoma & 1 & 3.3 \\
Myxoma & 1 & 3.3 \\
Nonspecific myositis & 1 & 3.3 \\
Ganglionic cyst & 1 & 3.3 \\
Malignant & 6 & 20 \\
Gaint cell tumor & 3 & 10 \\
Fibrosarcoma & 2 & 6.7 \\
Muscular sarcoma & 1 & 3.3 \\
\hline CT: & 2 & 6.7 \\
Intra muscular hemangioma & 1 & 3.3 \\
Myositis ossificans & 1 & 3.3 \\
\hline MRI: & & \\
Bengin & 23 & 76.7 \\
Complete tendon achilles tear & 2 & 6.7 \\
Partial thickness tear of tendon Achilles & 2 & 6.7 \\
Anterior talo-fibular ligament sprain & 1 & 3.3 \\
Posterior tibio-talar ligament sprain & 2 & 6.7 \\
Tibialis posterior and felxor tendonstenosynovitis & 1 & 3.3 \\
Post traumatic ifection + callus & 1 & 3.3 \\
Intra muscular hematoma & 2 & 6.7 \\
Intramuscular inflammatory lesion & 1 & 3.3 \\
Myositis ossificans & 1 & 3.3 \\
Fatty degeneration & 2 & 6.7 \\
Intra muscular lipoma & 2 & 6.7 \\
Intra muscular hemangioma & 3 & 10 \\
Intra muscular anscesses & 1 & 3.3 \\
Ganglionic cyst & 2 & 6.7 \\
Malignant: & 7 & 23.3 \\
Intra muscular sarcoma & 1 & 3.3 \\
Neurogenic & 2 & 6.7 \\
Metastasis and recurrence & 13.3 \\
\hline
\end{tabular}

Table (4): Validity of MRI in diagnosis malignant lesions in comparison to pathology and clinical as Gold standard:

\begin{tabular}{|c|c|c|c|c|c|}
\hline \multirow[b]{2}{*}{ MRI: } & \multicolumn{2}{|c|}{ Pathology \& clinical } & \multirow[t]{2}{*}{ Total } & \multirow[t]{2}{*}{ Kappa } & \multirow[t]{2}{*}{$\mathrm{P}$} \\
\hline & Malignant & Benign & & & \\
\hline Malignant & 5 & 2 & 7 & \multirow{3}{*}{0.70} & \multirow{3}{*}{$<0.001$} \\
\hline Benign & 1 & 22 & 23 & & \\
\hline Total & 6 & 24 & 167 & & \\
\hline Validity & \multicolumn{5}{|c|}{$\begin{array}{l}\text { Sensitivity: } 83.3 \% \text { Specificity: } 91.7 \% \\
\text { PPV: } 71.4 \%\end{array}$} \\
\hline Accuracy & \multicolumn{5}{|c|}{$90 \%$} \\
\hline
\end{tabular}

\section{DISCUSSION:}

Our study included 30 patients; males represented $60 \%$ while females represented $40 \%$, their age ranged from 3 to 75 years (mean age was 36.37 years), regarding the occupation, the specialists was the most affected followed by the students then house wives and farmers $(26.7 \%, 23.3 \%$, $16.7 \%$ \& $16.7 \%$ respectively) .This was in agreement with the study of Elgohary was conducted on 40 patients (12 females and 28 males) ranged in age between 12 and 60 years with mean age (mean \pm SD: 34.95 ) and the percentage of occupation among his 


\section{Hanan M. Arafa, et al.,}

patients $(25.9 \%, 23.8 \%, 16 \% .17 .7 \%)$ respectively ,however this was not in line with El-Liethy whose study was on 30 patients (18 females and 12 males) their age ranging from 18 to 50 (mean age 29.15) and the percentage of occupation among his patients $(20.7 \%, 26.3 \%, 13.7 \%, 22.5 \%)$ respectively ${ }^{(4 \& 5)}$.

About the underlying cause of lesion among our studied cases the non- traumatic lesions were 20 cases $(66.7 \%)$ and 10 cases $(33.3 \%)$ had a history of trauma mostly occurred during playing sports $(16.7 \%)$, this was in line the study of Fletcher whose study shows $67.2 \%$ were non-traumatic lesions and $32.8 \%$ were of traumatic lesions but differ from Nagata which the non-traumatic lesions were $35.9 \%$ and the traumatic lesions were $64.1 \%{ }^{(6 \& 7)}$.

According to the presenting symptoms and systematic comorbidity, the most frequent symptoms were pain followed by swelling and skin discoloration (36.7\%, $16.7 \%$ and $6.7 \%$ respectively) and 2 cases had systematic comorbidity one case had cancer breast and the other had hemolytic disorders, this agree with the study of Murphy which study $(36.1 \%, 17.1 \%$ \& 6.5 $\%$ respectively) and differ with Nagata which study $(8.7 \%, \quad 10.9 \% \quad \& 16.6 \%$ respectively) ${ }^{(8 \& 7)}$.

MRI findings among the studied cases are $76.7 \%$ have benign lesions most frequent is hemangioma $(10 \%)$, followed by ${ }^{(2)}$ complete tendon achilles tear ,partial thickness tear of tendon Achilles, posterior tibio-talar ligament sprain, intra muscular hematoma, intra muscular lipoma, ganglionic cyst (6.7) for each one and (3.3) for each one of the following :anterior talofibular ligament sprain, tibialis posterior \& felxor tendons tenosynovitis, post traumatic infection + callus, intramuscular inflammatory lesion, myositis ossificans and intra muscular abscesses, Also 23.3\% have malignant lesion most frequent is metastasis from other tumors $(13.3 \%)$ followed by neurogenic tumors $(6.7 \%)$ then intrtamuscular sarcoma (3.3\%), this in agreement with the study of Fletcher where the benign lesions $75.9 \%$ and the malignant lesions $24.1 \%$ and but not match with the study of Aga where the benign lesions $36.9 \%$ and the malignant lesions $63.1 \%$ and metastasis from other tumors ${ }^{(6 \& 9)}$.

The sensitivity of MRI in detection of malignant lesions compared to histopathology and clinical diagnosis as gold standard was $83.3 \%$, specificity was $91.7 \%$ and accuracy was $90 \%$ and the statistical significance agreement between two methods by Kappa test ,this is in line with Murphy that had sensitivity 84.1 $\%$,specificity $91.9 \%$ and accuracy $91 \%$ respectively ${ }^{(8)}$.

Summary: Our study included 30 patients; males represented $60 \%$ while females $40 \%$ with their age ranged from 3 to 75 years (mean age was 36.37 years), regarding the occupation; among the studied cases was specialists had the highest affection and about the underlying cause of lesion, the non- traumatic lesions were 20 cases $(66.7 \%)$ and 10 cases $(33.3 \%)$ of the studied cases had history of trauma.

According to symptoms and systematic comorbidities among the studied cases, the most frequent symptoms among the studied cases were pain, swelling and skin discoloration $(36.7 \%, \quad 16.7 \%$ and $6.7 \%$ respectively). Also 2 cases only had systematic comorbidity one case had cancer breast and the other had hemolytic disorders.

As to MRI findings , $76.7 \%$ had benign lesions most frequently hemangioma $(10 \%)$ and $23.3 \%$ presented with malignant lesion, majority was metastasis from other tumors $(13.3 \%)$

The sensitivity of MRI in detection of malignant lesions compared to histopathology and clinical diagnosis as gold standard methods was $83.3 \%$, specificity was $91.7 \%$ and accuracy was $90 \%$ and there 
were statistical significance agreement between two methods by Kappa test

\section{Conclusion:}

MRI is the modality of choice in evaluating lower limb muscular lesions due to its high soft tissue contrast resolution, and multi-planar capabilities. MRI may allow clinicians to more accurately estimate the time required before patient can return to normal life as well as the risk of recurrent injury.

\section{REFERENCES:}

1. Adams R.D. and Victor: Principles of clinical myology: diagnosis and classification of muscle diseasesPrinc Neurol (5th ed.), McGraw Hill Inc (1993), pp. 1184 1197

2. Sookhooa S., MacKinnona I. , Bushby K., Chinnery P.F., et al.: MRI for the demonstration of subclinical muscle involvement in muscular dystrophy Clin Radiol, 62 (2) (2007), pp. 160-165

3. Nagaty M, Aref S, El-Essawy S, Saied E, et al., 1999: Neuroimaging in muscle diseases. Neurology thesis Egypt. pp.

4. Elgohary MMIA, Abdul Rahim SAA, and Ibrahim TAA(2017): Role of MRI in evaluation of traumatic ankle injuties. The Egyptian Journal of Hospital Medicine; 69(3):2016-2024.

5. El-Liethy N, and Kamal H (2016): High resolution ultra-sonography and magnetic resonance imaging in the evaluation of tendino-ligamentous injuries around ankle joint. The Egy.

6. Fletcher, C.D.M., 2014: The evolving classification of soft tissue tumours - an update based on the new 2013 WHO classification. Histopathology, 64 (1), pp.211.

7. Nagata, S. et al., (2008): Diffusionweighted imaging of soft tissue tumors: usefulness of the apparent diffusion coefficient for differential diagnosis. Radiat Med, 26 (5), pp.287- 295.ptian Journal of Radiology and Nuclear Medicine; 47: 54355.22 .

8. D F Murphy, D A J Connolly, B D Beynnon (2003): Department of Orthopaedic Surgery, University of Vermont, Burlington, VT, USA; 10.1136/ .37.1.13.

9. Aga, P. et al., (2011): Imaging Spectrum in Soft Tissue Sarcomas. Indian Journal of Surgical Oncology, 2(4), pp.271-279. 


\section{Hanan M. Arafa, et al.,}

\section{دور التصوير بالرنين المغناطيسي في تثخيص امراض العضلات في الطرف السفلي}

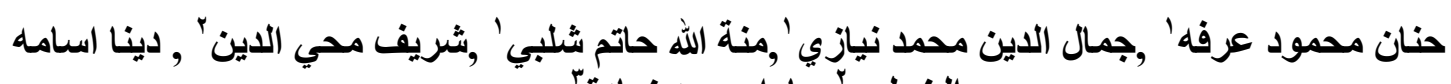

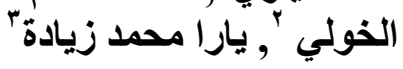

ا ـ قسم الاشعة النشخيصية ـ كلية الطب - جامعة عين شمس

Y _قسم الاشعة التشخيصية ـ معهذ بحوث امر اض العيون

بـ قسم الاشعة التشخيصيةـ الهيئه العامه للمسنشفيات و المعاهد التعليميه.

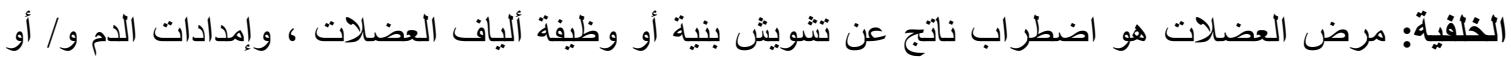

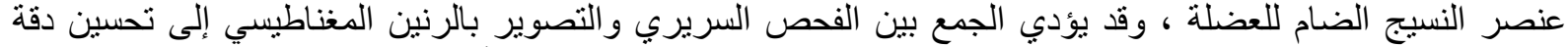

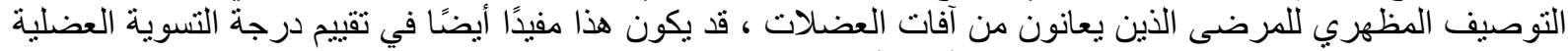

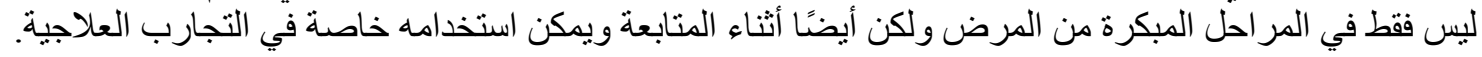
الهدف من العمل: تقييم دور التصوير بالرنين المغناطيسي في اكتشاف وتقييم أمراض العضلات وقيمتها النذير

المرضى والطرق: أجريت هذه الدر اسة في قسم الأشعة بجامعة عين شمس ، حيث شملت ثلاثين مريضًا ، وكان لائرة الايهم

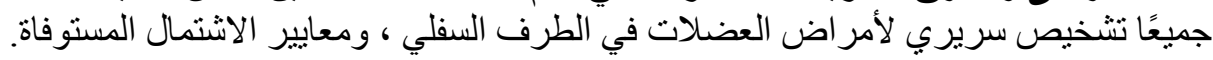

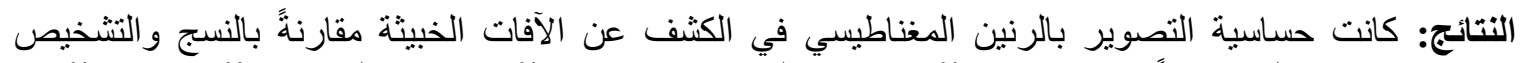

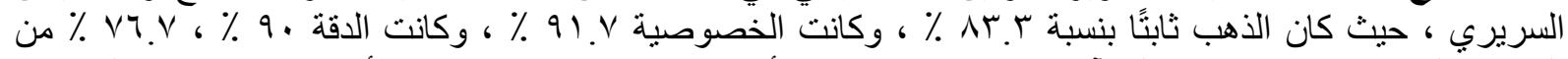

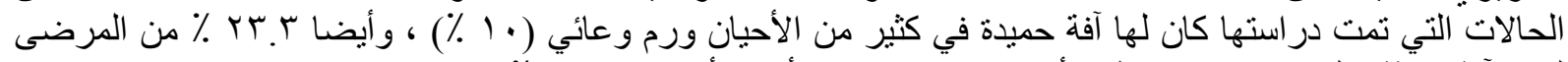

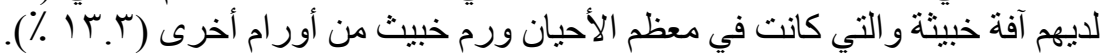

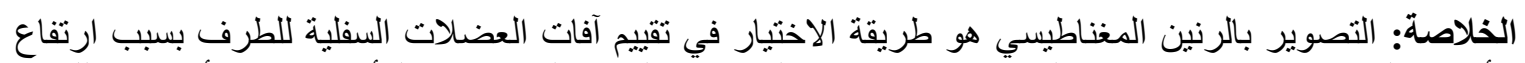

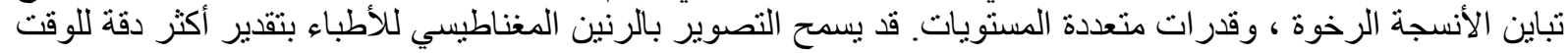
المطلوب قبل عودة المريض إلى الحياة الطبيعية بالإضافة إلى خطر الإصـابة المنكررة. 